\title{
ISLAMIC EDUCATION IN CIVILIZATION OF FASHION INDUSTRY: CLOTHES CONCEPT REFLECTION IN ISLAM
}

\author{
Ahmad Mustami \\ Sunan Kalijaga State Islamic University of Yogyakarta, Indonesia \\ E-mail: ahmadmustami@yahoo.co.id
}

\begin{abstract}
This article discusses the concept Apparel in Islamic education. This was currently a lot of variety of fashion in dress. Although the general function of clothes was a human genitalia cover and protect the body from the heat of the sun. However hijab at this time not just cover the nakedness, but rather as a fashion style that became a common thing now was infecting the womenfolk including Muslim. Ranging from clothes, pants, until hijab began in innovation so as to attract the eye. Although it is not yet represent the shape and fashion model/standard clothes, but felt able to express Islamic education in the dressing (hijab) and a fashion model/Islamic clothing. Obviously keep on religious norms, ethical and moral teachings. Substance of clothing in Islam is polite in accordance with the values of Islamic Education.
\end{abstract}

Keywords: Islamic Education, Clothes, Fashion, Genitalia

\section{A. Introduction}

The existence of various progresses and development of civilization which was sophisticated and fastcouldproduce a wide range of products used for human needs. One aspect that was growing and could affect human life was clothing industry, essentially clothing was a primary need that was needed by human in the world and its development was quite significant, it was proved by the establishment of garment factories with various models and materials around the world. 
Clothing is one of the basic human needs where clothing was very important for humans. While scientists stated that a new man knew clothes long time before humans got to know the needs of the board (Shihab, 2004: 29). According to them Homo sapiens, our ancestors came from Africa were stifling. Most of them moved from one place to another place. At the place and time they started to dress that originated from animal skins, their goal was to wear leather clothes to warm the skin.

A few years ago sewing leather was found, and clothing became growing. As we know that the Tuareg people in the Sahara Desert, North Africa, covering the whole of their body with clothes, for protection from the hot sun and sand flying in the open desert plain (Shihab, 2004: 31). On the other hand, clothing was also associated with a sense of beauty, also member of the psychological impact to the wearer. Clothing was also related to the culture and development of society.

Islam has also introduced the clothes that should be used by Muslims, especially for women whowore veil. The wearing veil in the sense of clothing that covered the entire body except, the face and hands of a woman who had been lack of attention to the Islamic community since the 19th century. It returned aboutthe last 5 years and seemedhaving more devotees. The problem was becoming increasingly widespread and rose to the national after many designers created diverse types of veils. The designers not only designed the type of veil but also introduced through models and famous artists displayed on several TV stations. Many people who watched and became a model in the use of hijab. Moreover nowadaysthere were various styles in wearing veil.

Now hijab clothes became one of the fashion hijab which was in demand by the public withsimple models and easy to use, especially with the spread of hijab tutorial with various models, and the important thing was the hijab became a trend nowadays. Many people vied to beautify themselves by wearing the hijab, even now many hijabers communities were established which became a place to share 
stories and up-date of the hijab trend today. The emergence of hijabers communities that are popular in the community not only become a community of ordinary woman, but always identified the high class community.

The recent hijab fashion culture boomed in Indonesia, especially in the modern world. In the present context, the hijab was not only a symbol of the identity of Muslims but also hijab became a symbol of identity, status, and someone'spower. In the modern Muslim societies, the veil was more often associated with upper class lifestyle. One thing that became our question was how the hijab fashion trends were rapidly able to provide significant changes in outlook in social life than previously considered only as a symbol / identity of a religious into a culture that was synonymous with modernity. We needed to know why it could shift the function of the hijab in ancient times and now that changed the stereotype hijab itself symbolically.

Many analyzes of the factors that favored the spread of the phenomenon of veiling among the Muslims. One factor that was also thought to be driving the rise of the veil was the economic factor. Or it could be as a gesture of defiance against the West which often used of double standards while insulting Muslims and their religion, there was also suspected that the use of the veil was a symbol of political views which were initially required by the groups of Islam with Muslim women or non-Muslim (Shihab, 2004: 1-2).

As Muslims we had to look at the rules of accordance dress with Islamic Shari'ah, so that what we wore could be accounted for in the hereafter and did not trigger things that were not desirable. In contrast to today a lot of models that were not in accordance with Islamic Shari'ah, for example, there was a lingerie model known as "you can see" which meant you could view, or even willing desperately to raise the bottom up and the top were willing to be lowered to the bottom, or anyone wearing that should be used by children kindergarten / elementary (super-tight clothing) so everybody could see what should not be seen. 
From the problems above, the writer would try to assess more about women's clothing in the Qur'an. How is the provision of women's dress actually and how the implementation of Islamic education in the world. Here the writer would use thematic using verses.

\section{B. Methods}

There were many methods used by the interpreters in interpreting the content of the Qur'an. If it was traced the development of the interpretation of the Koran since the beginning until now, would be found that in the outline the interpretation of the Koran was done in four ways (methods) were: Ijmali (global), Tahlili (analytical), Muqarin (perbandingann) and Maudhu'i (thematic) (Baidan, 2005: 3). The four methods would be explained in detail.

First, the Ijmalimethod (global) is a method that described the Qur'an verses briefly but included, in popular language, easy to understand, and easy to read. In addition, the presentation is not too far from the style of the Koran so that listeners and readers seemed to still hear the Koran whereas what they heard was its commentary (Baidan, 2005: 13).

Secondly, the tahlili method (analytical) was to interpret the verses of the Koran by describing all the aspects contained in the interpreted verses and explained the meanings included based on the expertise and the tendency to interpret the traveler who elaborated the verse. In this method, commentators usually elaborated the meaning contained in the Qur'an, verse by verse and surah based on the sequence in the Manuscripts (Baidan, 2005: 31).

Third, the Muqarin method (comparative) is 1) Comparing text of the verses of the Koran that had similarities editorialin two cases or more, and had different editorial in the same case; 2) Comparing the verses of the Koran to the hadith which outwardly appeared to conflict; and 3) Comparing the opinions of clerical interpretation in interpreting the Koran (Baidan, 2005: 65). 
Fourth, the Maudhu'i method (thematic) was to discuss the verses of the Koran according to the theme or title that had been set, all relatedparagraphs, collected. Then studied in-depth and thorough investigation of the various aspects associated with it, such as asbab al-nuzul, vocabulary. All explained thoroughly and in detail, and supported by the arguments or facts that could be justified scientifically, either argument was derived from the Qur'an, hadith, or rational thinking. From the description of the four methods above, the writer would choose the maudhu'i method in the discussion of the contents of the paper. Because using this maudhu'i method would be explained in detail and clearly about the concept of clothing.

\section{The Verse That Regard With Clothes}

The verses would be studied with regard to clothing as follows:

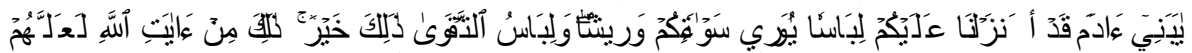

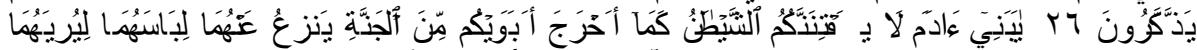

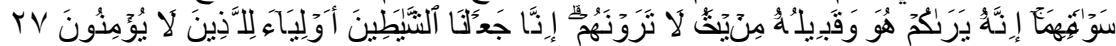

It means: Children of Adam! we have bestowed raiment upon You to cover yourselves (screen Your private parts, etc.) and as an adornment, and the raiment of righteousness, that is better. such are among the Ayât (proofs, evidences, verses, lessons, signs, revelations, etc.) of Allâh, that they may Remember (i.e. leave falsehood and follow Truth). Children of Adam! let not Shaitân (Satan) deceive you, as He got Your parents [Adam and Hawwa (Eve)] out of Paradise, stripping them of their raiments, to show them their private parts. Verily, He and Qabîluhu (his soldiers from the jinns or his tribe) see You from where You cannot see them. Verily, we made the Shayâtin (devils) Auliyâ' (protectors and helpers) for those who believe not (Q.S al-Araf: 26-27).

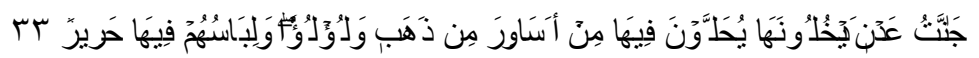

It means: 'Adn (Eden) Paradise (everlasting gardens) will they enter, therein will they be adorned with bracelets of gold and pearls, and their garments there will be of silk (i.e. In Paradise). (Q.S alFaathir: 33) 


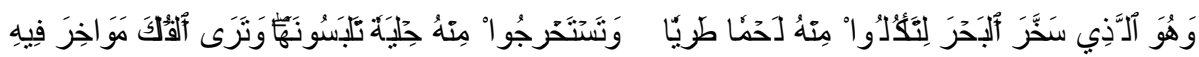

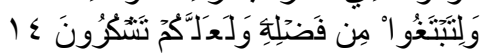

It means: and He it is who has subjected the sea (to you), that you eat thereof fresh tender meat (i.e. fish), and that You bring forth out of it ornaments to wear. and You see the ships ploughing through it, that You may seek (thus) of his Bounty (by transporting the goods from place to place) and that You may be grateful. (Q.S Surat AlNahl: 14)

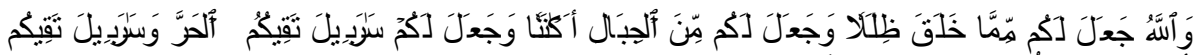

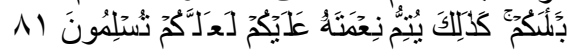

It means: And Allâh has made for you out of that which He has created shades, and has made for You places of Refuge In the mountains, and has made for You garments to protect You from the heat (and cold), and coats of mail to protect You from Your (mutual) violence. Thus does He perfect his Grace unto you, that you may submit yourselves to his will (in Islâm). (Q.S an-Nahl 81)

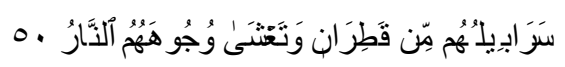

It means: Their garments will be of pitch, and Fire will cover their faces. (Q.S Ibrahim: 50).

\section{Clothing in general and Islamic Perspective \\ 1. Clothing in General Perspective}

Apparel by language was everything attached to the body from head to toes. Meanwhile, according to the term was something that we wore everyday from head to toes with all its equipment, such as handbags, shoes, and all kinds of jewelry attached to it.

Definition of clothing (headscarf) in Arabic Lisanul was Hijab means shawl, or clothes that women wore wide to cover the head, chest and the back of his body (Mandzur, tt: 272). Whereas in AlMu'jamal referee, hijab means clothes inside (the robe) or shawl (khimar), or clothes to cover all women's clothes to cover all the outer part of the body as well as a coat. In Mukhtar Sihah, hijab came from Ka Ja Ibu, attractive or collecting, while the width of the veil means garments such as coats. Clothing (apparel) was one of the basic human 
needs in addition to food (food) and shelter (the board) (http://muslimberjilbab.blogspot.com/2005/03/busana-muslimidentitas-dirimuslimah.html)

Thereforeit was deduced that the clothes (veil) could be interpreted as loose clothing or veil covering women veil, or clothing covering dress and veil women wore, or all wore, or all of the clothes that covered the body of women.

\section{Clothing in Qur'an Perspective}

In the Qur'an used three terms for clothing, namely Libas, Tsiyab, and Sarabil.

\section{a. Libas}

Libas word in the Koran. Libas originally meant covering, everything was covered. Clothes function as cover clothing was very clear. However, it should be noted that this did not necessarily mean "covering the genitalia", because the ring coveredfinger also called libas. Indeed, we might say that that covered the entire body except the face and (palms) hands, following the verses, perhaps even excessive. But at the same time we were unnatural stated against those who did not wear a veil, or that revealed her hands, that they "definitely had violated religious instruction." Doesn't the Qur'an mention limitation of genitalia? The scholars also haddifferent opinion (Shihab, 2006: 188-189).

When talking about the sea, the Qur'an Al-Nahl verse 14 states that:

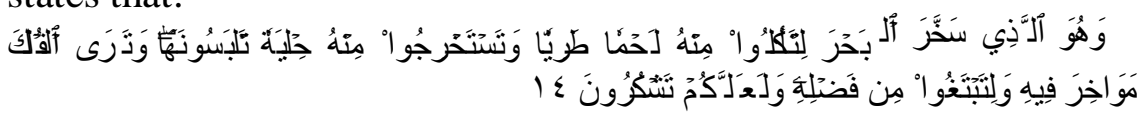

It means: and He it is who has subjected the sea (to you), that You eat thereof fresh tender meat (i.e. fish), and that You bring forth out of it ornaments to wear. and You see the ships ploughing through it, that You may seek (thus) of his Bounty (by transporting the goods from place to place) and that You may be grateful (Q.S Nahl:14). 
Libas word used in the Qur'an to show the inner and outer clothing.

b. Tsiyab

This word in the Qur'an was used to indicate the inner clothing. The word was derived from the word tsaubmeant returning, i.e. the return of something in its original state, or in circumstances which should correspond to the first idea. The phrase stated that "originally was the idea, and finally was a reality". This expression meant that the fact should be returned to the original idea, because the reality was a reflection of the original idea.

Raghib al-Isfahani was an expert on the language of the Qur'an, stated that the clothes was named tsiyab or tsaub, because the basic idea for clothing materials were to be used. If these materials spun into clothing, then in fact it had returned to the basic idea of its existence.

Then it was explained in $\mathrm{Al}-\mathrm{A}$ 'raf verse 22:

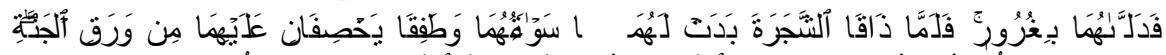

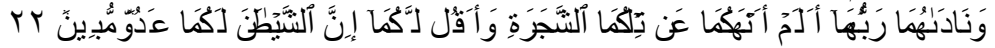

It means: So He misled them with deception. Then when they tasted of the tree, that which was hidden from them of their shame (private parts) became manifest to them and they began to stick together the leaves of Paradise over themselves (in order to cover their shame). and their Lord called out to them (saying): "Did I not forbid You that tree and tell you: Verily, Shaitân (Satan) is an open enemy unto you?"(Q.S al-A'raf ayat 22).

From the paragraph above it was clear that the basic idea contained in humanwas the "closing of the genitalia", but because of the temptation of the devil, human genitalia opened. Thus, the genitalia were covered with clothes would be returned on the fundamental idea. It was reasonable if the clothing was named tsaub or tsiyab which meant "something that returned genitalia to the basic idea", which was closed. The idea of opening genitalia was the idea of the devil. 
c. Sarabil

Dictionaries defined the word as clothing, any type of materials. Sarabil words could be interpreted as a function of clothing to protect themselves from the heat, the cold and the danger of war. Only two verses that use the word, which in Surah al-Nahl verse 81 which was defined as clothing that serves to ward off the heat, cold, and the danger of war. Later in the letter Ibrahim verse 50, the punishment that would be experienced by sinners in the hereafter: their clothes were from the Sedan (Shihab, 2009: 155-157).

\section{The Terms of Muslim Clothing}

The requirements of Muslim clotheswere as followedwhich was quoted from the Hijab book Al - mar'ah kitabi wa Al Sunnah Muslim Fil (Shaykh Al Albany):

a. Covering the entire body besides the excluded condition

This was contained inAn Nuur verse 31 Allah said: "Say to the believing women:

It means: "Let them hold their views and maintain their genitals and they must not reveal their adornment except that (usually) appear on them. And let them shut the veil cloth to their chest, and do not reveal their adornment".

Covering the face and two hands was not obligatory for women; even there is no prohibition to reveal the jewelry found on the face and two hands that are already commonly known, such as shadow and nail polish that is never separated from women (Muthahari, 2002: 68).

Also the word of God in Al-Ahzab: 59, which reads: "O Prophet, tell your wives, your daughters and Mu'min wives:

It means: O Prophet! tell Your wives and Your daughters and the women of the believers to draw their cloaks (veils) All over their bodies (i.e.screen themselves completely except the eyes or one eye to see the way). That will be better, that they 
should be known (as free respectable women) so as not to be annoyed. And Allâh is ever Oft-Forgiving, Most Merciful.

M. Quraish Shihab had different views in interpreting the verse above; he stated that Allah commanded not to wear Muslim headscarves. The opinion was as follows: The verse above did not command Muslim women to wear the hijab, because at that time most of them had been wearing it, but the way to wear it was not in accordance with desired paragraph above. This impression was obtained from the editorial paragraph above which stated their headscarves and commanded was "Let them hold it." Ifagainst those who had to wear the hijab, certainly it could be more for those who did notwear it, God said: "Let them put out her head scarf" (Shihab 2003: 321).

b. The function was not as a jewelry

In Nur Syam's book "Not Different World, Islamic Communication Sociology explained that Islamic dress style had been entered paradox globalization. In one side someone wanted to show the Islamic dress style with veil as headgear, but on the other side of the body protrusion was also invisiblein this term the "beauty"by naked eyes. Contemporary fashionable hijab had become a popular trend among women as essentially an example of the workings of the global system that was very prominent paradox (Sham, 2005: 59).

This was based on the word of Allah in Surah an-Nur verse 31, which reads:

It means: "And do not women that reveal their adornment".

In general, the content of this paragraph also included regular clothes if decorated with something that caused men stared their view of her. This was confirmed word of God in the Al-Ahzab verse 33: 
It means: "And you shall remain in your house and do not ornate and behave like people of ignorance".

\section{c. Opaque}

In a hadith the Prophet had said: "At the end of my mother there would be women who were dressed but (virtually) naked. Above their heads as there iwas a hump (hump) camel. Curse them because in fact they were women who damned! "In another hadith there was additional:

It means: "They will not go to heaven and will not smell heaven it can be kissed on the trip so and so". (H.R. Muslim of history Abu Hurarirah)

d. Not strictly to show the curves

Usamah bin Zaid had said: The Messenger never gave clothes Quthbiyah thick clothes which are awarded by Dihyah al-Kalbi to him. Akau even then put the clothes on my wife. The Prophet asked me:

It means: "Why weren't you wearing Quthbiyah?" I replied: "I put the clothes on my wife".

The Prophet then said:

It means: "Tell her to wear clothes in behind Quthbiyah it, because I was worried that clothes could still describe the shape of the bones". (H.R. Ahmad and Al-Bayhaqi with Hasan sanad).

Aisha once said:

It means: "A woman in the prayer should wear three suits: dress, veil, and khimars". Aisha was never reached its izar (similar clothing robe) and veiling her.

e. Not to resemble men's clothes in terms of identity

Someone's identity which everyone basically had a desire in her to determine her identity not to accept the resignation of identity because of dominating or ruling. Subjects who previously 
had a stable and unified identity would be fragmented not only one but also multiple identities; which sometimes gave contradictions such event or identity. According to Goffman in Nasrullah (2012: 113) any activity involved the other people.

Abu Hurayrah said: "The Prophet cursed the man who wore women's clothes and women who wore men's clothes". Abdullah bin Amru said: "I heard the Messenger of Allah said:" Excluding our group of women who equated ourselves with men and men who equated themselves with women ". Abdullah bin Umar said: "Messenger of Allah said:" Three groups were not going to heaven and God would not look at them on the Day of Judgment; people were disobedient to parents, women behavedlike men and likening herself to men and dayyuts (people who did not have jealousy) ".

In the hadiths contained clear instructions about Prohibition of women behavior who resembled men, and vice versa. Not resemble men's clothes here, for example, a Muslim woman wore trousers like worn by a man, wearing men's shirts etc. So psychologically affected at private users, for example, was as strong as a man, feels tomboy and others.

f. Wearing clothes not to seek popularity

Any clothes that was used with the aim to gain popularity in the middle of the crowd, either the clothes was expensive, worn by one to be proud of the world and jewels, or clothes that lowvalue, which was used by one to reveal majesty for showing off. Ibnul Athir said: "Syuhrah meant visibility of something. Libas syuhrahwas well known among those who raised their eyes to her. She was proud to others with haughty and arrogant behaviour "(http://muslimahberjilbab.blogspot.com.).

\section{E. The Islamic Education Values in Clothes}

1. Clothes to cover genitalia

The word genitalia (aurat), which wastaken by 'ar wordmeant trouble, shame, reproach. The ugliness was not only in someone selves, but it 
could also be caused by other factors that led to be bad. None of the body part was bad, because everything was fine and valuable including genitalia. Nevertheless, the people saw, the "visibility" was bad.

Of course a lot of things that were bad, each person could judge. Religion also gave a clue about what it thought genitalia or sau-at. In its function as a cover, of course, clothes could cover everything reluctantly shown by the user, as well as whole body. But in the context of talking guidance or religious law, genitalia understood as certain limbs that could not be seen except by certain people.

\section{Clothes for Protection (Taqwa)}

On the other hand, clothes gave a psychological effect for the wearer. It was because many countries to change his military clothes, after military defeated. Even Kemal Ataturk in Turkey, prohibited the use of tarbusy (a type of headgear for men), and ordered to replace them with Western-style hat, because he considered tarbusy affected the attitude of his nation and a symbol of backwardness.

In daily life we could feel the influence of psychological clotheswhen we attended a party. When dressed poorly, or not in accordance with the situation, the wearer would feel uncomfortable, or even loss of confidence, the opposite was the case. Sufis, deliberately woreshuf (wool) were rough in order to produce a positive influence in their lives. Indeed, it must be admitted that the clothes did not create the students, but he could encourage users to behave like students or otherwise become vicious, depending on how and models of clothes. Respectable clothes invited someone to behave as well as visiting places of honor, at the same time to prevent indecentspots. This is one ofthe Koran by ordering women to wear such veil so that they were easier to be known (as a Muslim / respectable women) so that they were not disturbed.

The function of protection for clothes could also be appointed for spiritual cloth. Libas-at-taqwa. Everyone was required to knit herself 
this outfit. Yarns or a fiber was repentance, patience, gratitude, qana'a, pleasure, and so on.

Faith was naked, his clothes were taqwa.

\section{Clothes as a Bookmark Identity}

Identity or personality was something which illustrated the existence as well as differentiating it from the others. The existence or presence of someone was material and also immaterial (spiritual). The material things were reflected in the clothes she wore.

We could know at once distinguish primary and secondary school pupils, or the Navy and the Army, or the Corporal and General by looking at what she wore. There was no doubt that the clothes were functional identity and distinguish a person from others. Even sometimes it distinguished a person's social status.

Rasul Saw greatly emphasized the importance of the appearance of Muslim identity, including through clothes. Therefore:

It means: The Prophet forbade the man who wore women's clothes and women's wore male clothes. (Transmitted by Abu Daud)

People's personality had to exist. When the prophet discussed how the most appropriate way to deliver / invite Muslims to pray, then there were some his companions who proposed self-adhesive signs, so that those who saw would come. He did not agree. There was another that proposes to use trumpet, and he commented: "It's the Jewish way". Some also proposed to hide the bell. "That's how Christians", the words of his. Finally Azan which we know now was approved by the prophet he is the call to prayer that we know today.

Immaterial personality (spiritual) even emphasized by the Qur'an through Al-Hadid (57): 16:

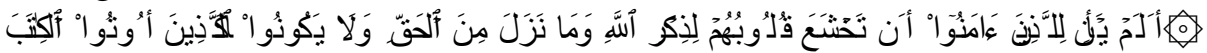

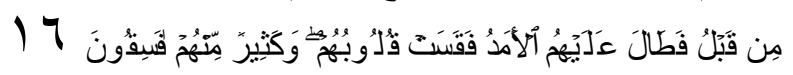

It means: has not the time come for the hearts of those who believe (in the Oneness of Allâh - Islâmic Monotheism) to be affected by Allâh's Reminder (this Qur'ân), and that which has been revealed 
of the truth, lest they become as those who received the Scripture [the Taurât (Torah) and the Injeel (Gospel)] before (i.e. Jews and Christians), and the term was prolonged for them and so their hearts were hardened? and many of them were Fâsiqûn (rebellious, disobedient to Allâh).

A Muslim was expected to wear clothes that described the spiritual and physical identity. Fully realized that Islam did not come specify certain clothes fashion, so that every society and period, might determine the mode that suited her. However, such did not seem excessive if it was expected that the dress was also reflected in the identity. There was no doubt that the veil for women was a picture of a Muslim identity (Shihab, 2007: 212-220).

\section{Clothes as Someone's Guide Personality}

Everyone had their own personalitylike the personal traits they possessed. The characteristicswere what distinguished a person to another. Personality was actually anabstract problem, could only be viewed through performance, action, speech, dress, and in facingevery problem. The real personality was abstract (ma'nawi), difficult to be seen or known to be real, the appearance or the mark in all facets and aspects of life could be known. For example in his actions, speech, how to get along, dressed, and in dealing with any issues or problems, whether mild or severe.

Personality was the entirety of an individual comprising physic and physical elements. In such sense, the whole attitude and one's actions was a picture of the personality of the person, if it had done consciously. And a good deed was often said that people did not have a good personality or didn't have noble morals. Therefore, the problem of personality was something that determined the level of authority of a teacher in the view of the students or the community. In other words, good or not someone's image was determined by personality. More so for a teacher, personality problems were the factors that determined the success of duty as educators. Personality 
could determine whether teachersbecame good educators and coaches or a destroyer or destroyer for the future students, especially for students who were still young (elementary level) and those who suffered frommental shocking (youth level).

Personality was a decisive determined the familiarity of relationship among teacher students. Teacher's personality would be reflected in the attitudes and actions in fostering and guiding students. So, no one could become a true teacher (noble) unless he made himself as part of the students who seek to understand about the students' difficulty in learning and other difficulties outside of learning problems, which could inhibit the learning activity of students then the teacher would be lovedby the students.

For example, teachers had to have a personality that could be used as profile and idol, his whole life was a complete figure. That was the impression of the teacher as an ideal figure. Few of the teachers did little or no good, would reduce the authority and charisma slowly melting of identity. Therefore, personality was a very sensitive issue at all. Unification of words and actions that were required by the teachers, not another word to deed, like saying goes, oblate outside tapered inside.

Teacher was a partner for students in good things. Good teachers, students became good too. There was no teacher who intended plunged the students into the contempt valley. Because of the glory of teachers, the various degrees bear. Teachers were heroes selfless, unsung hero, a hero of science, hero goodness, hero of education, being versatile, or with a nickname like interpreters, artist, friend, a good citizen, humanbuilders, the carrier of culture, pioneer, reformer and reliable, pillar, teacher deity, a teacher (Djamarah, 2005: 39-41)

\section{F. Conclusion}

From the explanation above, it could be concluded that the clothes were basic human needs that we wore every day from the toes and all equipment. In this article the writer used a thematic method. In the Qur'an there were three terms used for clothes, namely: Libas was 
pointing inner and outer clothes. Tsiyabwas to show inner and outer clothes. Sarabilwas clothes whose function was to protect the hot, cold and war.

The educational values embodied in clothes, namely: Clothes as cover nakedness, Clothes as a protector (taqwa). Clothes were as a bookmark identity. Clothes were as a hint of one's personality, especially a teacher. As Muslims we had to look at the rules of dress in accordance with Islamic Shari'ah. So that what used reflects the personality of an Islamic Muslim. 


\section{References}

Baidan, Nashruddin. (2005). Metodologi Penafsiran al-Qur'an. Yogyakarta: Pustaka Pelajar.

Djamarah, Syaiful Bahri. (2005). Guru dan Anak Didik : Dalam Interaksi Edukatif. Jakarta: Rineka Cipta.

Error! Hyperlink reference not valid. 2015/ 04/ busana-muslimidentitas diri/ mulimah.

Shihab, M. Quraish. (2006). Jilbab pakaian wanita muslimah, pandangan ulama' masa lalu dan cendekiawan kontemporer. Jakarta: Lentera Hati.

. (2003). Tafsir Al-Mishbah, Pesan, Kesan dan Keserasian al-Qur'an. Jakarta: Lentera Hati.

- (2004). Jilbab Pakaian Wanita Muslimah. Jakarta: Lentera Hati. . (2000). Wawasan al-Qur'an: Tafsir Maudhuli atas Berbagai Persolaan Umat, Bandung: Mizan. . (2007). Wawasan al-Qur'an: Membumikan alQur'an. Bandung: Mizan. . (2009). Wawasan al-Qur'an: Tafsir Tematik dan belbagai Persoalan Umat. Bandung: Mizan.

Mandzur, Ibnu. (tt). Lisanul Arab. Beirut: Dar Shadir.

Muthahhari, Murtadha. (2002). Wanita dan Hijab Terj. Oleh Nashib Musthafa. Jakarta: Lentera Basritama.

Nasrullah, R. (2012). Komunikasi Antarbudaya di Era Budaya Siber. Jakarta: Kencana Prenada Grup Media.

Syam, Nur. (2005). Bukan Dunia Berbeda Sosiologi Komunitas Islam. Surabaya: Pustaka Eureka. 